\title{
兵庫県周辺地域におけるイワナの潜在生息域の推定
}

\author{
河口洋一 ${ }^{1} \cdot$ 三橋弘宗 ${ }^{2} \cdot$ 田中哲夫 ${ }^{3} \cdot$ 三橋亜紀 ${ }^{4}$ \\ 1 北海道大学大学院農学研究科 060-8589 札幌市北区北 9 条西 9 (yoichi@for.agr.hokudai.ac.jp) \\ ${ }^{2,3}$ 兵庫県立人と自然の博物館 流域生態研究グループ 669-1546 三田市弥生が丘 6 丁目 \\ (2hiromune@hitohaku.jp, ${ }^{3}$ f-tanaka@hitohaku.jp) \\ 4 神戸市在住
}

\section{Predicting the potential habitat of white-spotted charr in central Japan}

Yôichi KAWAGUCHI ${ }^{1}$, Hiromune MITSUHASHI ${ }^{2}$, Tetsuo TANAKA ${ }^{2}$ and Aki MITSUHASH ${ }^{3}$

${ }^{1}$ Department of Forest Science, Graduate School of Agriculture, Hokkaido University, N9 W9 Sapporo, Hokkaido, 060-8589 Japan

${ }^{2}$ Museum of Nature and Human Activities, Hyogo, 6-Yayoiga-oka, Sanda, Hyogo, 669-1546 Japan

\section{はじめに}

野生生物の保全計画を立案するためには，対象 とする種の現時点での分布を明らかにするだけで はなく，環境要因との対応関係から潜在的に生息 することが可能な地域を明らかにする必要がある (USFWS, 1981)。一般に, 数百 $\mathrm{km}$ 四方の広範囲に わたって, 各種の詳細な分布を明らかにすること は困難なうえ, 時期や環境変動の影響により発見 出来ない場合もあるため, 現況の分布情報を収集 するだけでは現地を評価することは不十分である。 特に，保全の対象として取り上げられることが多 い希少種の場合，環境改変によって地域的な絶滅 が引き起こされていることが多く，過去には生息 していたが現在は確認できない場合があり，分布 情報も乏しい.そのため, 現況調查や既存の文献調 査から分布情報を可能な限り抽出し, その種の分 布を制約する環境要因との関連性から潜在的な生 息域を推定する手法の確立が求められている（三 橋・池田, 2001).

山地渓流に生息する冷水性のサケ科魚類である イワナ(Salvelinus leucomaenis)の生息域は, 日本列 島レベルの広域的な分布情報をもとに検討された ところ，源流域における河川水温の指標值となる 地下水温の推定值（GWT）によって制約されるこ とが知られている（Nakano et al., 1996）.しかし, 実際の保護区設定などの保全対策を想定した場合 には, 日本列島レベルより小さな流域スケールで の潜在的な生息域を推定することが求められてお り，スケールに相応した環境要因を選択しなけれ ばならない(Wiens, 1989; Saab, 1999).したがって， 広域的な潜在生息域に対して,さらに流域スケー
ルでの景観要因によって領域を絞り込む必要があ る。これまで, 流域スケールでのサケ科魚類を対象 とした研究では, ハビタットの孤立化, ハビタット サイズや流域の平均傾斜角，人為圧 (道路密度)な どの景観要因のパラメータが個体群の有無に関連 していることが知られており（Faush et al., 1994; Dunham and Rieman, 1999), 保全計画への適用が検 討されている。

一方，国内での河川性サケ科魚類の生息域に関 する研究は, 微細生息場所 (Urabe and Nakano, 1999）や流程, 小流域レベル（Inoue et al., 1997）に ついては行なわれてきたが，小流域レベルよりも 大きなスケールでの研究は殆ど行なわれておらず, 景観要因との対応関係は明らかにされていない. そこで本研究では, 兵庫県とその周辺域 (鳥取県東 部)を流れる河川を対象とし, 地下水温の推定値に 関する閾值（Nakano et al., 1996）を用いて，広域 的に生息可能な領域を推定し，この領域に対して, 現地調査および既存の魚類相調査資料による分布 情報と各種景観要因との関係から，より詳細な領 域を絞り込むアプローチを採用した。特に，八ビ タットサイズについては, メタポピュレーション 構造や個体群の存続に大きく関連するため (Fahrig and Merriam, 1994), 地下水温の推定值によって規 定される閾値に基づいて推定し，個体群の有無と の関連性を検討する.またここれらの解析プロセス を経て得られたパラメータに基づき，地理情報シ ステム（GIS）を活用して, 地図として潜在生息域 を表示することを試みた.なお,この研究は未だ発 展途上の段階であり, 現在さらなる分布情報と環 境情報の充実を図り再度解析を行なっている．関 
心のある方は, 別報にて報告する予定であるので， 詳細はそちらを参照して頂きたい。

\section{方法}

イワナ(Salvelinus leucomaenis)の分布情報は， 1998-2000年にかけて現地調査を行ない確認したも のを, 1/25,000 地形図（国土地理院）に地点を記録 した。また，過去の調査資料 (報告書) や文献に基 づいて詳細な地点の情報を収集し, 同様に地図上 の位置を特定した。最近の研究では, 広域的な分布 を検討する場合には, 個体数や現存量でなく, 分布 の有無であっても環境要因との対応関係を定量化 できることから（Oberdorff et al., 2001），広く情報 を集積し, 分布する地点だけでなく, 過去に分布が 記録されていないことを識別するためデータべー ス化を行なった。

環境要因について, 気温, 積雪量は平年値の気 象メッシュ（気象庁：3次メッシュ）を，標高につ いては数值地図 $50 \mathrm{~m}$ メッシュ (国土地理院: 約 $50 \mathrm{~m}$ メッシュ)をそれぞれ用い, 傾斜については数值地 図 $50 \mathrm{~m}$ メッシュから数値計算によって求めた．地 下水温の推定値（GWT）は, 緯度と標高からモデ ル式（Nakano et al., 1996）により推定することで $250 \mathrm{~m}$ メシュのデータとした. また河川について は, 1/25,000地形図に記されているラインを読み取 りベクトルデータに変換した．これらのデー夕作 成及び以後の解析は, すべて地理情報システム (Arc View 3.2 and Spatial Analyst, ESRI 社) を用い た.

広域的なイワナの潜在生息域を規定する環境要 因として, 地下水温の推定值 (GWT) が $16^{\circ} \mathrm{C}$ 以下 とされていることから (Nakano et al., 1996), この 䦭值によって生息可能領域をGIS上で抽出した。次 に, GWTが $16^{\circ} \mathrm{C}$ 以下の領域を流れる河川で，イワ ナの分布が確認された小流域とイワナの分布が確 認されていない流域について，各流域の平均 GWT, 流域の平均積雪量, 流域の平均標高, 流域 の平均傾斜, $\mathrm{GWT} 16^{\circ} \mathrm{C}$ 以下の流路長といった景観 要因を各小流域の解析単位として属性情報を取得 した。

イワナの潜在生息域を判別するために，イワナ の分布の有無を従属変数に, 景観要因を独立変数 として線形判別関数による判別分析を行なった (SPSS 9.0, SPSS社). 判別分析によって得られた各 小流域の判別得点から, イワナの分布が確認され
た流域の判別得点でもっとも小さい值を基準に， その值以上の小流域を兵庫県とその周辺域におけ るイワナの潜在生息域として地図上に表した。

本研究の対象とした兵庫県周辺地域は, 東北地 方や中部地方に比べるとイワナの生息に適した冷 水温となる高い標高を有する山岳地带がそしく, イワナの分布は兵庫県と鳥取県の県境付近に位置 する水ノ山及び扇ノ山の周辺に偏っており，分布 の局所性と乱獲が関連して兵庫県が独自に作成し たレッドデータブックでは最も絶滅の危険性が高 いAランクに位置付けられている（兵庫県, 1997).

\section{結果と考察}

野外調査及び文献によって確認されたイワナの 分布地点は, 兵庫県と鳥取県の県境付近に集中し, 現地調査から分布が確認された地点は 10 地点だっ たのに対し，既存資料から分布が確認された地点

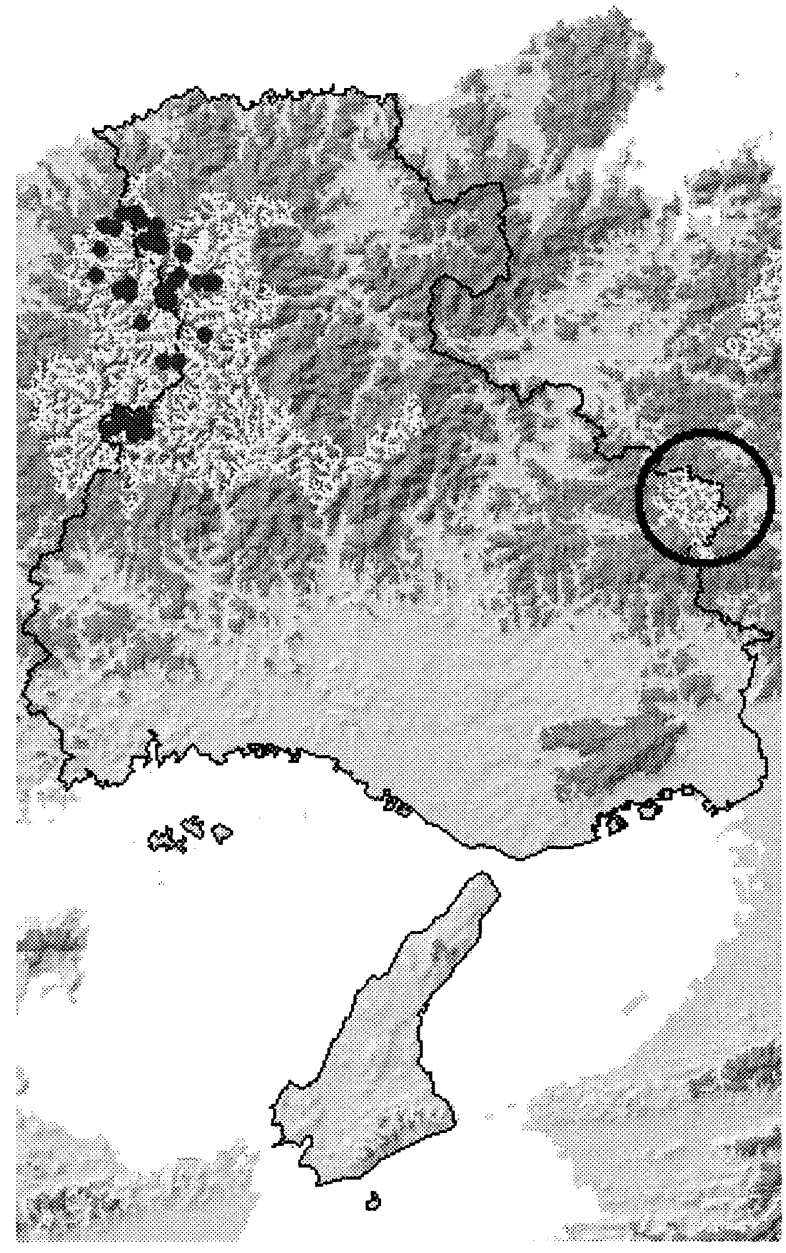

図 1. 地下水温 (GWT) $16^{\circ} \mathrm{C}$ 以下の領域（濃灰色 部分）とイワナの分布地点, そして判別得点 によって選ばれたイワナの生育可能な流域 （地図上に示された円の中の小流域はイワナの 分布が確認されていない) 
は46地点（現地調査によって確認された地点と重 複する場合も含む)だった. 現地調査から分布を確 認することは確実な手段であるが, 既存の調查結 果を見直す作業からも多くの情報を得ることが可 能である.

イワナの生息が可能と考えられる地下水温の推 定值 (GWT) が $16^{\circ} \mathrm{C}$ 以下の領域を地図表示すると, 実際の分布地点を内包した広い範囲が選択された (図 1 ).GWTの推定には緯度と標高の值を用いる が, 今回の対象範囲では緯度の変化に比べて標高 の変化が大きく, 領域の大半は高い標高を有する 山地が占めていた。

次に,より詳細なスケールでイワナの潜在生息 域を推定するために, 先に推定した領域に対して, 過去の文献資料等を参照して小流域を解析単位と したイワナの分布の有無について, 各景観要因を 説明変量として判別分析を行なった。その結果, GWTが $16^{\circ} \mathrm{C}$ 以下の領域の内, イワナの生息してい る流域と生息していない流域を景観要因によって 有意に判別することができ（ $\chi^{2}=278.09, \mathrm{P}<$

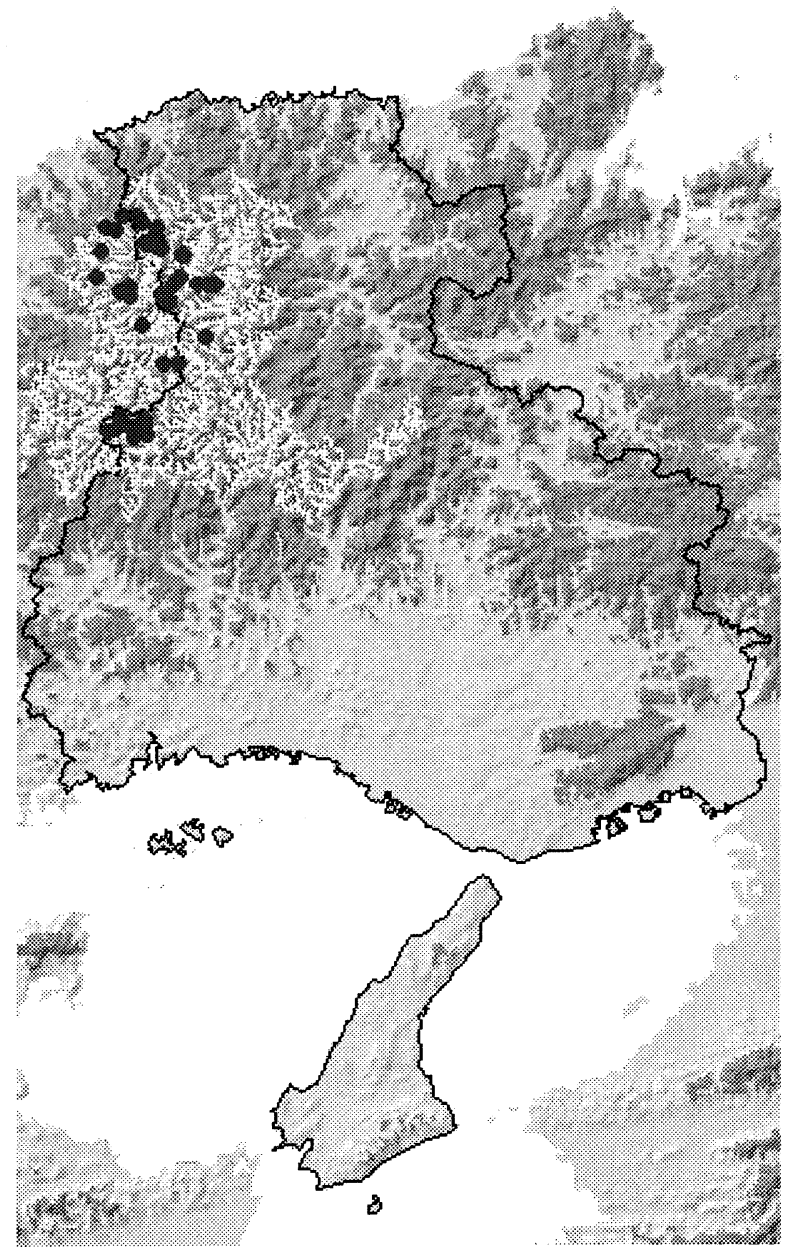

図2. 判別得点によって推定されたイワナの潜在 的な生息域
0.001 , 正判別率 $=87.5 \%), \mathrm{GWT} 16^{\circ} \mathrm{C}$ 以下となる流 路長 $(D=0.76)$, 平均積雪量 $(D=0.44)$, 平均標 高 $(\mathrm{D}=0.20)$ が判別に寄与していた. 特に, GWT16 ${ }^{\circ} \mathrm{C}$ 以下の流路長は, 判別に大きく寄与しており, イ ワナの生息域サイズと関連すると考えられる。こ れまでの研究でも, 生息域サイズが小さくなると, 絶滅確率が高まることで, 個体群の維持が困難に なると考えられており（Fahrig and Merriam, 1994; Dunham and Rieman, 1999), 兵庫県周辺地域におい て,イワナにとっての許容可能な流路長が比較的 短い小流域では個体群の維持が難しいと考えられ た．河川性の魚類の場合には他の分類群とは異な り，川に沿った線的な移動を余儀なくされるため に, 生息域の矮小化と孤立化が及ぼす影響は比較 的大きいと考えられている (Zwick, 1992; Nakano et al., 1996). また, 平均積雪量や平均標高について は, 河川水温を低下させる要因となるため, 水温と の擬似相関となっている可能性がある。

判別得点に基づきイワナの潜在生息域をより詳 細なスケールで絞り込むことが出来たが(図1), 過 去にイワナの分布が記録されていない流域も選択 されているため,さらに小流域ごとに生息域の質 を検討した.まず, 実際にイワナの分布が確認され た地点から GWT の閾値を検討したところ，GWT はすべて $14.8^{\circ} \mathrm{C}$ 以下であり，閾值として用いた 16 ${ }^{\circ} \mathrm{C}$ りも約 $1{ }^{\circ} \mathrm{C}$ 低い值であった。 そこで, GWTが $14.8^{\circ} \mathrm{C}$ 以下の流域をより好適な生息域として位置付 け, その妥当性を検討するため, 前述した解析によ り選択された小流域を対象に, GWTが $14.8^{\circ} \mathrm{C}$ 以下 となる流路長を説明変量に追加して, 再度判別分 析を行った. その結果, イワナの分布の有無を有意 に判別することができ $\left(\chi^{2}=176.61, \mathrm{P}<0.001\right.$, 正 判別率 $=100 \%)$, 平均積雪量 $(\mathrm{D}=0.57)$, 平均標 高 $(\mathrm{D}=0.38), \mathrm{GWT} 14.8^{\circ} \mathrm{C}$ 以下となる流路長 $(\mathrm{D}=$

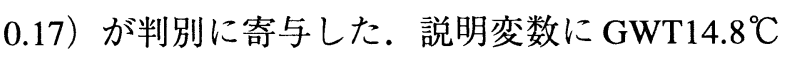
以下の流路長を組み込むことで, 正判別率が高ま ることから，イワナの全国的にみた許容限界が 16 ${ }^{\circ} \mathrm{C}$ であり，好適と考えられる領域は $14.8^{\circ} \mathrm{C}$ 以下と 解釈したが, この点は今後の検討が必要である.

判別得点に基づいて, 地図上にイワナの潜在生 息域を示す（図 2). 兵庫県とその周辺域でイワナ の潜在生息域として選択された河川は, 既存情報 から自然分布が確認されている日本海側の 3 河川 (岸田川水系, 矢田川水系, 円山川水系) と瀬戸内 海側の 1 河川 (千種川水系), そして過去に報告が 
なかった瀬戸内海に流れる 2 河川（揖保川水系, 市 川水系）となった．瀬戸内海側に流れる2河川は， これまでイワナの自然分布は確認されてこなかっ たものの，放流個体が採集されることが度々あり (三橋, 私信), 環境要因から考えるとイワナの生息 が可能であると考えられる．現実に自然分布が確 認されない要因としては, 生物地理学的な障壁効 果が関連すると思われる。

今回の結果について, GWTの数值自体は厳密な 絶対值ではなく，むしろ相対值として捉えること が望ましい.GWTは源流から流下するにしたがっ て環境要因や人為改変の影響が複合されて，モデ ル式からの乘離が大きくなるため, 実際の河川水 温を反映しない可能性がある.したがって, 今回の 結果をそのまま他の地域に適用するのは難しい. しかし, GWTによって規定される流路長によって 定義した生息域サイズが個体群の維持に関与する 可能性が高く, 特にこの流路長が短い小流域では, 水路網の繋がりを考慮した面的な保全計画 (Johnson and Gage, 1997) の必要性が示唆される.

\section{引用文献}

Dunham, J. B. and Rieman, B. E. 1999. Metapopulation structure of bull trout: influences of physical, biotic, and geometrical landscape characteristics. Ecological Applications 9: 642-655.

Fahrig, L. and Merriam, G. 1994. Conservation of fragmented populations. Conservation Biology 8: 50-59.

Faush, K. D., Nakano, S. and Ishigaki, K. 1994. Distribution of two congeneric charrs in streams of Hokkaido Island, Japan: considering multiple factors across scales. Oecologia 100: 1-12.

兵庫県. 1997. ひょうごの野生動物: 絶滅が心配さ れている動物達. 神戸新聞総合出版センター.

Inoue, M., Nakano, S. and Nakamura, F. 1997. Juvenile masu salmon (Oncorhynchus masou) abundance and stream habitat relationships in northern Japan. Canadian Jounal of Fisheries and Aquatic Sciences 54: 1331-1341.

Johnson, L. B. and Gage, S. H. 1997. Landscape approaches to the analysis of aquatic ecosystems. Freshwater Biology 37: 113-132.

三橋弘宗・池田啓. 2001. フィールドワークの軌跡 が語る生態系のすがた. GIS Japan 1 : 93-98.

Nakano, S., Kitano, F. and Maekawa, K. 1996. Potential fragmentation and loss of thermal habitats for charrs in the Japanese archipelago fue to climatic warming. Freshwater Biology 36: 711-722.

Oberdorff, T., Pont, D., Hugueny, B. and Chessel, D. 2001. A probabilistic model characterizing fish assemblages of French rivers: a framework for environmental assessment. Freshwater Biology 46: 339415.

Saab, V. 1999. Importance of spatial scale to habitat use by breeding birds in riparian forests: a hierarchical analysis. Ecological Applications 9: 135-151.

Urabe, H. and Nakano, S. 1999. Linking microhabitat availability and local density of rainbow trout in lowgradient Japanese streams. Ecological Research 14: 341-349.

U.S. Fish and Wildlife Service. 1981. Standards for the development of suitability index models.Ecological services manual 103. U.S. Department of Interior, Fish and Wildlife Service,Division of Ecological Services. Government Printing Office, Washington, D.C., USA.

Wiens, J. A. 1989. Spatial scaling in ecology. Functional Ecology 3: 385-387.

Zwick, P. 1992. Stream habitat fragmentation - a threat to biodiversity. Biodiversity and Conservation 1:8097. 